\title{
VEGETATION OF THE EASTERN ARCTIC BETWEEN 2.595-2.554 Ma (Data from Lake El'gygytgyn, North-East Russia)
}

\author{
A. V. Lozhkin', A. A. Andreev",4, P. M. Anderson ${ }^{3}$, Yu. A. Korzun ${ }^{1}$, E. Yu. Nedorubova ${ }^{1}$ \\ ${ }^{I}$ North-East Interdisciplinary Scientific Research Institute n. a. N. A. Shilo, FEB RAS, Magadan \\ ${ }^{2}$ Alfred Wegener Institute Helmholtz Center for Polar and Marine Research, Telegrafenberg A43, \\ 14473 Potsdam, Germany \\ ${ }^{3}$ Quaternary Research Center, University of Washington, Seattle WA, USA \\ ${ }^{4}$ Institute of Geology and Petroleum Technologies, Kasan Federal University, \\ 420008 Kasan, Russia \\ E-mail:1ozhkin@neisri.ru, korzunjulie@mail.ru, super.exidia@yandex.ru, \\ aandreev@uni-koeln.de,pata@uw.edu
}

\begin{abstract}
The Pliocene-Pleistocene boundary, set at $2.588 \mathrm{Ma}$ or the base of the Gelasian age, represents a shift in global climates from those of the comparatively warm Pliocene to the cooler conditions of the Pleistocene. Lake El'gygytgyn (Chukotka) provides one of the few continuous terrestrial records that permits a close examination of this important transition in Earth's climate states. The MIS 102-MIS 103 portion of the El'gygytgyn palynological record indicates that, during the earliest Pleistocene, this area of the Arctic was vegetated by closed Larix-BetulaAlnus forest. Such vegetation contrasts to that of the latest Pliocene, when Larix forest-tundra dominated, and differs from the herb and shrub tundra found today in northern Chukotka. This earliest period of the Gelasian represents the climatic optimum for MIS 103. Even under the most severe conditions during MIS 102, Larix forest-tundra persisted, which differs greatly from the herb tundra that characterized many glacial intervals in the Arctic during the Late and Middle Pleistocene.
\end{abstract}

Keywords: Gelasia, Pleistocene, Pliocene, pollen analysis, paleovegetation.

DOI: 10.34078/1814-0998-2019-4-38-46

In the continuous annals of changing Arctic biocenoses, the interval 2.595-2.554 Ma occupies a special place. This interval corresponds to stages 103-102 of the marine oxygen-isotope (MIS) scale (Lisiecki, Raymo, 2005) and includes a key chronostratigraphic marker in the Gauss-Matuyama boundary $(2.588 \mathrm{Ma})$, which occurs within MIS 103 . Perhaps most importantly, this isotope stage also encompasses the transition from the Neogene to the Quaternary period. The placement of the PliocenePleistocene boundary has been debated since 1948, in part because initial global cooling that ultimately led to the build up of continental scale glaciers which are the hall mark of the Pleistocene, began in the late Tertiary $\sim 2.8-2.4$ Ma ago (Gibbard et al., 2010). Consequently, many Quaternary scientists favored an earlier age for this boundary, whereas Neogene stratigraphers argued for the retention of

(C) Lozhkin A. V., Andreev A. A., Anderson P. M., Korzun Yu. A., Nedorubova E. Yu., 2019 the original definition. In 1982 at an INQUA meeting in Moscow, the Vrica site in Calabria, southern Italy, was suggested as the stratotype for the lower boundary of the Pleistocene. In 1996, the Executive Committee of the International Union of Geological Sciences (IUGS) approved a new division for the Pliocene named the Gelasian age, whose Global Stratotype Section and Point (GSSP) was located at Vrica. Finally, in 2009 the IUGS approved a proposal by the International Commission on Stratigraphy to lower the basal age of the Gelasian using new data from Monte San Nicola, Sicily. Here the GSSP lies $1 \mathrm{~m}$ above the Gauss-Matuyama paleomagnetic boundary (Rio et al., 1998; Lourens, 2008). The astronomically tuned age of $2.588 \mathrm{Ma}$ has been rounded to $2.58 \mathrm{Ma}$ and is now considered as the correct Pliocene - Pleistocene boundary (Fig. 1).

Even after six decades of debate, the PliocenePleistocene boundary remains important for stratigraphic questions and paleoenvironmental reconstructions, especially for understanding the changes 


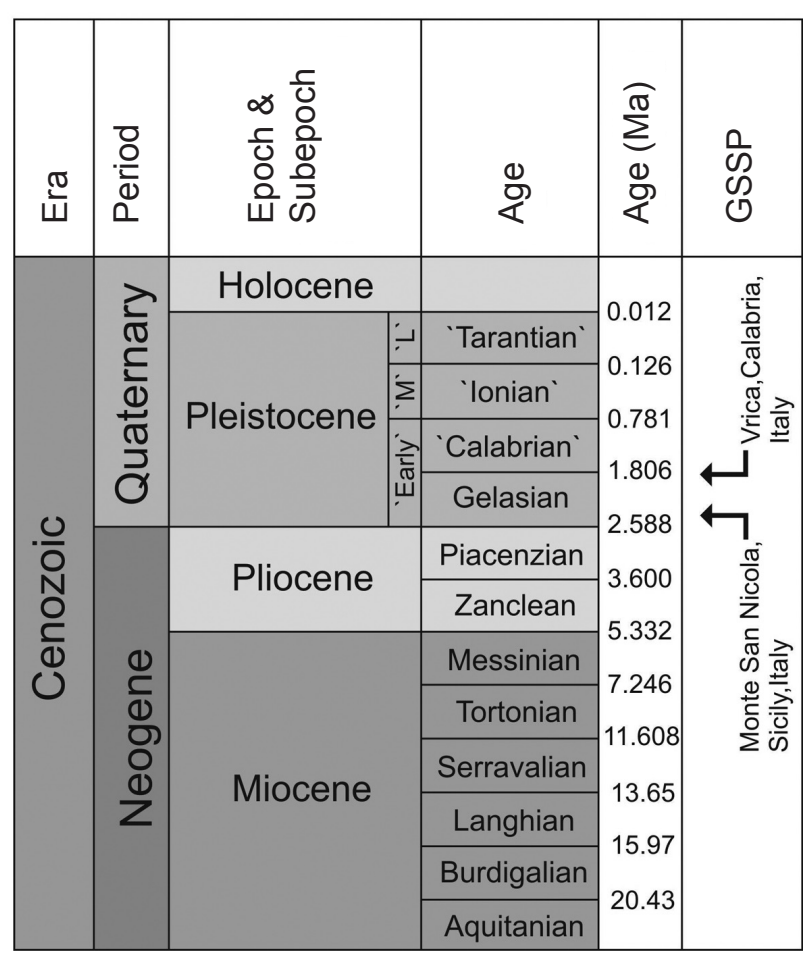

Fig. 1. Late Quaternary stratigraphic scheme from the International Union of Geological Sciences (IUGS). Arrows mark the ages of key sites used in determining the Pliocene-Pleistocene boundary

Puc. 1. Позднечетвертичная стратиграфическая схема от Международного союза геологических наук (IUGS). Стрелками отмечен возраст ключевых участков, использованных при определении границы плиоцена и плейстоцена

in global climate systems that resulted in an ice-age Earth. In that regard, the need remains to improve understanding of ecosystem responses to cooling conditions through the addition of terrestrial records, particularly in sensitive regions like the Arctic. Such a unique chronicle exists in the continuous sediment record from El'gygytgyn Lake. The lake formed $\sim 3.6 \mathrm{Ma}$ ago following a meteorite fall beyond the Arctic Circle in Chukotka at $67^{\circ} 30^{\prime} \mathrm{N}, 172^{\circ} 05^{\prime}$ (Fig. 2). El'gygytgyn Lake provides the longest continuous record of changes in arctic environments, a record that spans the late Neogene and the Quaternary (Melles et al., 2012; Brigham-Grette et al., 2013; Wennrich et al., 2016). In 2009, the "El'gygytgyn Drilling Project" raised several cores (site 5011-1), which combined to include the total 317-meter thickness of sediments (Melles et al., 2012). An age model was established for the composite core (D1), built in part on magnetic events recorded in the sediments including the Gauss-Matuyama boundary; an age of $\sim 3.6 \mathrm{Ma}$ was estimated for core D1 (see Wennrich et al., 2016 for more details).

Andreev et al. $(2014,2016)$ examined the changes in vegetation as earth's climate systems shifted from the Pliocene to the Pleistocene with a particular fo- cus on the 2.7-2.5 Ma interval. They concluded that climate deteriorated at the start of the Pleistocene as indicated by the establishment of steppe and tundralike communities. However, this climate change was not linear with warmer conditions occurring at several times during the Early Pleistocene. While employing both qualitative and quantitative interpretive techniques, the paleovegetation reconstructions relied heavily on a biomization approach (Prentice et al., 1992; Tarasov et al., 1998). In this method, pollen types are assigned to major vegetation formations or biomes according to modern ecology, bioclimatic characteristics of plants, and spatial patterns of modern pollen distribution. Thus, biomization focuses on broad-scale vegetation characteristics, particularly vegetation structure (e. g., conifer forest, shrub tundra, steppe) as modified by climate type (e. g., cool, dry). Smaller scale variations and characteristics of the vegetation are not the primary focus of this approach.

New samples from MIS 102 and MIS 103 have been added to those reported by Andreev et al. (2016) to fill in some levels where palynological data previously were unavailable. In particular, we have added a sample (sample number 04337, depth $123.552 \mathrm{~m}$, age $2.588041 \mathrm{Ma}$ ), which according to the El'gygytgyn age model corresponds precisely to the 2.588 Ma Pliocene-Pleistocene boundary. The spore-pollen spectrum is very close in composition to the spectra of samples taken above the PliocenePleistocene boundary described by Andreev et al. The assemblage from the $2.588 \mathrm{Ma}$ sample is dominated by pollen from trees and shrubs, including Betula (39\%), Alnus (43\%), Larix (3\%), and Salix (1\%). Herbaceous plants are represented mainly by Poaceae ( $8 \%$ ) and Cyperaceae (2\%). Sphagnum $(20 \%)$ and Polypodiaceae $(7 \%)$ are the most common spores.

In this paper, we re-examine the vegetation history during this important stratigraphic transition with a focus on the vegetation communities within the El'gygytgyn crater and the surrounding Anadyr Plateau. As described by Andreev et al. (2016), biome models used in reconstructing the paleovegetation of Siberia and the Russian Far East are not without their innate biases (e. g., the Bigelow et al., 2003 model tends to under-represent cold deciduous forest, whereas the model applied to the El'gygytgyn data (Tarasov et al., 2013) uses fewer tundra classifications, resulting in preferential assignment of certain herb assemblages to steppe as opposed to dry tundra). Consequently, we decided on using a more qualitative approach. The paleovegetational interpretations presented here are based on knowledge of modern ecology, comparison of fossil to modern pollen spectra, and an understanding of modern pollen-vegetation-climate relationships at northern high latitudes and in the Russian Far East. 

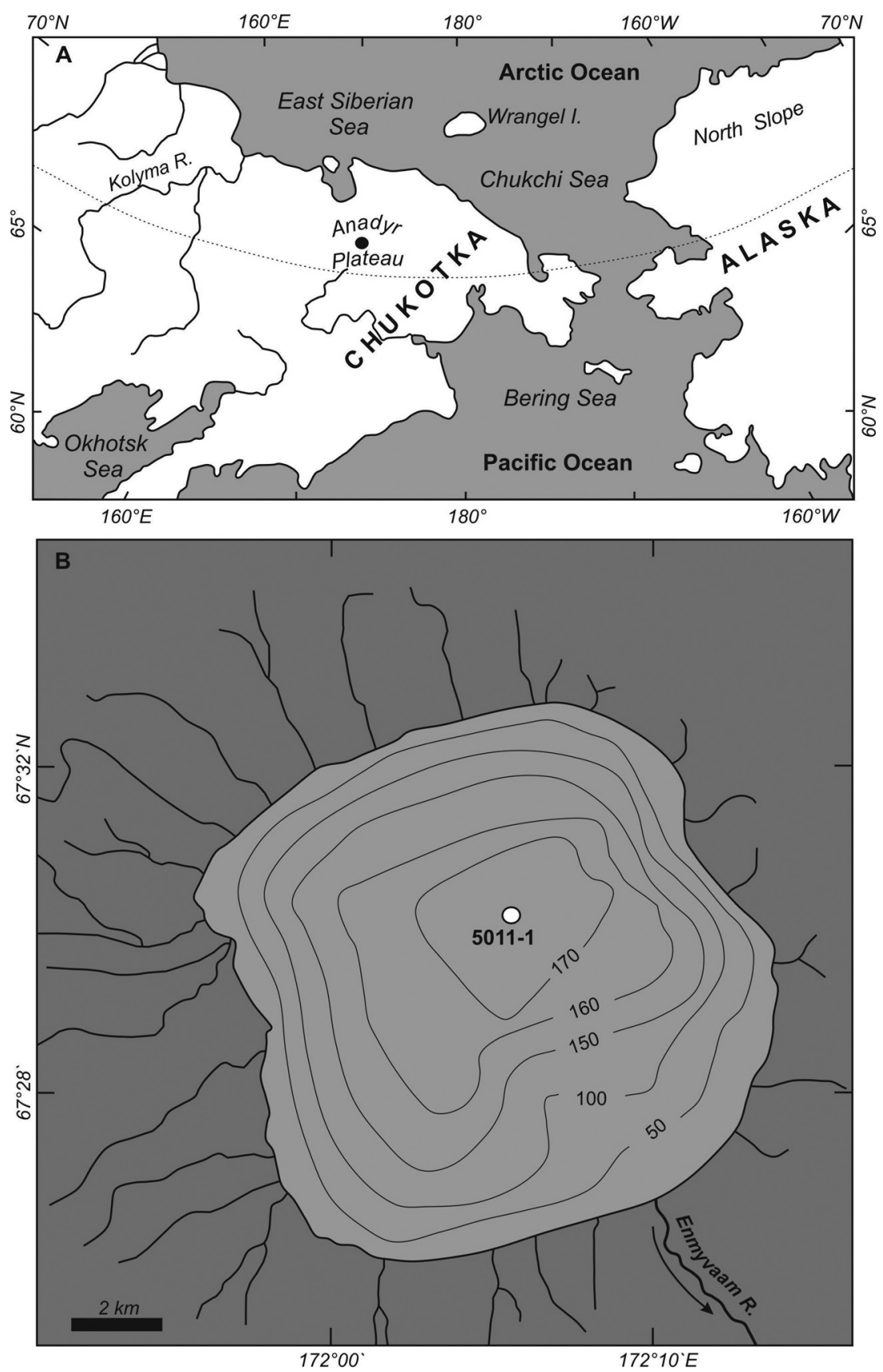

Fig. 2. Maps showing: A - location of El'gygytgyn Lake (black circle), B - bathymetry of the lake. Depths are in meters

Puc. 2. Карты, показывающие местоположение оз. Эльгыгытгын (черный круг) - А и батиметрию озера - В. Глубина в метрах

The pollen diagram has been divided into 7 zones based on changes in percentages of the major pollen taxa (Fig. 3). Percentages of individual taxa are based on a sum of arboreal, nonarboreal, and unknown pollen. Spores are expressed as percent of the pollen sum. Subsum percentages (Trees and Shrubs, Herbs, and Spores) are based on the sum of all pollen and spores. Zone 1 is from the Late Placenzian age of the Pliocene epoch. Zone 2 through zone 7 encompass the lower Gelasian age (MIS 102 and MIS 103 ) with the Pliocene-Pleistocene boundary occur- ring in mid-MIS 103. The current herb-dominated tundra within the El'gygytgyn crater differs from the shrub tundra of the surrounding Anadyr Plateau. However, study of modern pollen samples from lacustrine sediments indicates that the large lake, not surprisingly, captures much windblown pollen and thus reflects more the regional than local vegetation (Lozhkin et al., 2007; Matrosova, 2009). Therefore, the following descriptions unless otherwise noted reflect the broader scale vegetation.

The persistent occurrence of Larix and high percentages of Betula pollen in zone 1 (2595$2588.4 \mathrm{ka}$ ) indicate the presence of Larix forest-tundra both within the crater and likely across the Anadyr Plateau. Larix is a large pollen grain which preserves poorly. Thus, its appearance, even in trace amounts, is strong indication of the tree's presence on the landscape. High percentages of Betula pollen (> 20\%) in modern samples from northeastern Siberia generally are associated with the presence of shrub Betula, suggesting its growth in the understory of Larix stands and as an important component of shrub tundra in interfluvial areas, perhaps occurring as dense thickets (yerniki) on gentle slopes (Anderson et al., 2002a,b; Lozhkin et al., 2002). However, the presence of tree Betula can not be discounted. For example, Betula platyphylla, $B$. lanata, and B. ermanii occur within the modern light coniferous forest in coastal areas of the Magadan region. Alnus pollen is $<5 \%$ in zone 1 , indicating that it was rare on the landscape. Pinus subg. Haploxylon pollen (likely from the shrub Pinus pumila) registers above presence/absence threshold levels (Anderson et al., 2002a,b) in only the basal sample, suggesting that the conifer played a limited role in the vegetation during early MIS 103 with subsequent input of Pinus pollen during zone 1 representing long-distance wind transport. Both local and regional tundra likely was characterized by graminoid dominated communities, especially as indicated by high Cyperaceae pollen percentages. 


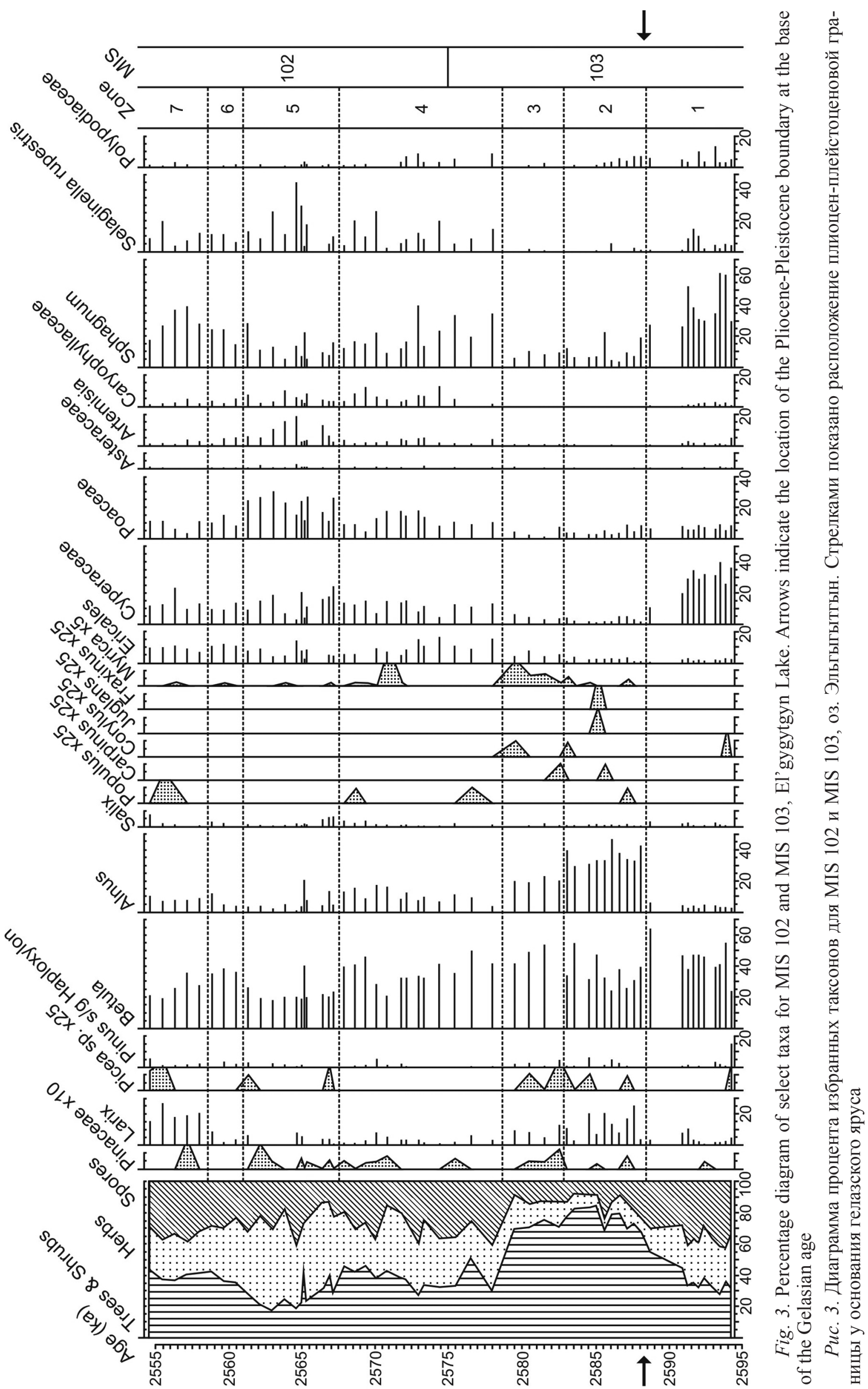


Cyperaceae grows across a wide range of ecologies, but often are associated with mesic to boggy areas, the presence of the latter clearly suggested by high percentages of Sphagnum spores. However, the moderate presence of Selaginella rupestris spores suggest disturbed areas on slopes, most likely within the crater.

Zone $2(2588.4-2582.7 \mathrm{ka})$ represents the climatic optimum for the interval $\sim 2.595-2.554 \mathrm{Ma}$. The vegetation is characterized by Larix-Betula forest, which grew within valleys and rolling upland of the plateau and within the crater. The extremely high percentages of Larix pollen in most samples suggest a closed forest (e. g., today in areas of the Kolyma valley with dense Larix forests, modern pollen samples typically contain $<2 \%$ Larix and in some samples the pollen is absent (Anderson et al., 2002a,b). Additionally, dense gallery forests with Larix, tree Betula, tree Alnus (e. g., Alnus hirsuta), Populus, and perhaps tree Salix dominated the valley bottoms. Chosenia arbutifolia is common today in gallery forests in southern areas of northeast Siberia. This species may also have been present in zone 2, but its pollen is indistinguishable from Salix. The high percentages of Alnus pollen ( $>30 \%$ ) perhaps indicate that these streamside forests were especially rich in tree Alnus, although thickets of shrub Alnus also were present. Similar gallery forests are found today in southern areas of northeast Siberia. Larix cajanderi is the dominant modern species, but Larix sibirica characterized the forests of northeast Siberia before MIS5 (Vas'kovsky, 1959). Trace amounts of Picea pollen appear in several levels, perhaps indicative of the limited establishment of this evergreen conifer. However, it is more likely that the grains represent long-distance transport. Pinus perhaps is present in small numbers, but $<10 \%$ Pinus subg. Haploxylon pollen suggests that like Picea, the grains are from a population to the south and/ or west of El'gygytgyn (Lozhkin et al., 2002). The minor and sporadic presence of pollen from Carpinus, Corylus, Juglans, and Fraxinus in zone 2 supports the "exotic" nature of the conifer pollen, because it is unlikely that these more temperate broadleaf trees grew in the region at this time. However, their appearance, albeit in trace amounts, does imply a northward movement of a more temperate forest boundary. The reduction of Cyperaceae and to a lesser extent Poaceae pollen to generally $<10 \%$ is a further indication of the extensive establishment of closed forest. However, variable but moderate percentages of Sphagnum spores and consistent appearance of ericaceous pollen suggest the presence of wetter substrates and heath communities. Such associations are common within present-day open Larix forest. However, given the overall character of the pollen assemblage it seems more probable that these taxa reflect the presence of heaths within the crater.
Myrica, which appears for the first time in the diagram, also grows in peaty areas, but the taxon also is found along lake shores, in the forest understory, and wet meadows.

Zone $3(2582.7-2578.6 \mathrm{ka})$ is marked by declines in Larix and Alnus pollen but with no change in Betula pollen percentages. The shift in the zone 2zone 3 assemblages suggests an opening of the LarixBetula forests and/or a more limited extent of forest, particularly on the plateau. With this shift to cooler and perhaps drier conditions, shrub Betula may have become a more common landscape element, for example as yerniki or as a member of the forest understory. Alnus probably continued to occur in both tree and shrub forms, although its presence on the landscape decreased as compared to the earlier zone. Ericales pollen, while variable, shows increased percentages, indicating an expansion of local heath communities. A slight increase in Myrica pollen, while still remaining a minor taxon, indicates the persistence or perhaps some expansion of mesic peats and meadows. However, graminoid pollen is generally $<10 \%$ suggesting a restricted presence of lakeside meadows and/or the continued regional importance of forest.

Trends in the pollen data that began in zone 3 (e. g., decreases in Alnus and Larix pollen, increase in pollen of Ericales) continue in zone 4 (2578.6$2567.5 \mathrm{ka}$ ), indicating further climatic deterioration and reduction of forest on the landscape. The zones also are differentiated by increases in graminoid and ericaceous pollen and Sphagnum and Selaginella rupestris spores in zone 4. Caryophyllaceae pollen, absent since zone 1, again is present reaching relatively high percentages $(\sim 5-10 \%)$ by mid-zone 4 . The change in the palynological assemblage indicates the establishment of Larix forest-tundra on the plateau. Tree and shrub Betula remained key members of both forest and tundra communities, although lower pollen percentages suggest that during mid-zone their importance decreased. The lowered percentages of Alnus pollen (generally $<10 \%$ ) indicate its continued decline. By zone 4, tree Alnus may have been absent or occurred rarely, with the pollen representing shrubs that perhaps were restricted primarily to streamside thickets and to mesic soils of hillside draws. The increase in herb pollen suggests an additional opening of the landscape, which began in zone 3. Higher percentages of ericales pollen and Sphagnum spores argue for the continued expansion of heaths and boggy terrain, certainly within the crater and likely across the plateau. However, the increase in Selaginella rupestris spores and a lesser increase in Artemisia pollen suggest that disturbed and/or xeric habitats were a greater element of slope vegetation than previously. This change may reflect primarily a habitat shift within the crater, but the continued increase in percentages of these taxa 
in zone 5 may point towards a more regional, climate related trend. High percentages of Caryophyllaceae pollen is a characteristic of glacial intervals in the El'gygytgyn record and has been associated with an increased importance of meadows near the lake (e. g., Lozhkin et al., 2007). Higher Caryophyllaceae pollen percentages may also reflect local expansion of meadows, but species within this cosmopolitan family are also associated with shrub thickets and disturbed, well-drained soils of streamsides.

The highest herb pollen percentages, particularly Artemisia and Poaceae, occur in zone 5 (2567.5$2560.9 \mathrm{ka}$ ), and percentages of Selaginella rupestris spores reach their maximum. Betula pollen percentages are at their lowest in the diagram, and Alnus pollen with the exception of 2 samples remains below the modern threshold $(>20 \%)$ for the taxon's presence (Anderson et al., 2002a,b; Lozhkin et al., 2002). Larix pollen occurs in all of the samples in the zone, although often in trace amounts. The palynological assemblage thus indicates the continued loss of forested areas with the dominant vegetation on the plateau being Betula-Salix shrub tundra. Lar$i x$ was probably restricted to valley bottoms, forming a sparser gallery forest as compared to previous zones, and to isolated stands in protected sites away from valleys. Alnus, if present, was not common and occurred only in shrub form. The increase in herb pollen implies an open regional landscape. Additionally, increased percentages of Artemisia and Selaginella rupestris suggest greater habitats with xeric soils and/or disturbed areas most likely on slopes and streamsides. However, percentages of ericales pollen and Sphagnum spores indicate the continued importance of heath communities and boggy terrain. Graminoid-forb meadows may have been more common locally and across the plateau.

Zone 6 (2560.9-2558.5 ka) is marked by increased Betula, decreased Poaceae, and the continued decline in Artemisia pollen percentages. These changes suggest improved climates and expansion of Larix foresttundra. Betula was the most common shrub in the tun$\mathrm{dra}$. The mosaic nature of the vegetation, indicating a mix of mesic to xeric and stable to disturbed settings, continues as described in the previous zones.

The dramatic increase in Larix pollen in zone 7 (2558.5-2554 ka) marks the second episode when Larix forest was widespread. In contrast to zone 2, herb pollen percentages are greater, particularly for the graminoids, whereas Betula pollen percentages, especially in upper zone 7, are less than in zone 2. These differences in the pollen assemblages suggest that while Larix was common in zone 7, the forests probably were more open than those established during the earlier climatic optimum. The relatively low percentages of Betula pollen may indicate that the taxon played a more restricted role in the vegetation as compared to the zone 2 forest. However, modern lacustrine samples from the Magadan region where Betula occurs as both trees and shrubs indicate presence/absence thresholds of $\sim 15 \%$, with most samples having $\geq 20 \%$ Betula pollen (Anderson et al., 2002a,b). Thus, it seems likely that Betula was found within the shrub understory as well as in tree form. Alnus pollen percentages also are significantly lower in zone 7 , suggesting a limited local or regional presence (e. g., $<10 \%$ in the fossil spectra is below the $\sim 20 \%$ presence/absence threshold in modern samples). Furthermore, tree Alnus most likely was absent, given the low values in the fossil spectra and its inferred occurrence in shrub form in zones 4-6. Populus and perhaps tree Salix / Chosenia were members of the gallery forest, with Alnus, Salix and Betula forming streamside thickets. The high percentages of ericales pollen and Sphagnum spores indicate the persistence of heaths and boggy habitats. This landscape may be reminiscent of that found today along the northern coast of the Okhotsk Sea, where a mix of open Larix forest and peatland is common. Low to modest percentages of xeric and/ or disturbed ground indicators, such as Selaginella rupestris and Artemisia, suggest these settings were not common on the landscape. As is the case for the other zones, Pinus subg. Haploxylon pollen occurs in minor amounts indicating the absence of the conifer in the El'gygytgyn region. If this pollen type is from Pinus pumila, closed forest, certainly present in zone 2 and perhaps in zone 7, would not favor the establishment of this coniferous shrub as it requires an open canopy. However, this factor is not relevant for the other zones with more open landscapes. In these settings the absence of Pinus pumila would suggest that dry winter conditions (i. e., insufficient snow cover to protect the evergreen shrub from winter dessication) rather than cool summers (Pinus pumila and Larix share similar summer temperature requirements) prevented its establishment in the crater or on the plateau.

The palynological data from the $2.595-2.554 \mathrm{Ma}$ interval from the Lake El'gygytgyn record traces changes in arctic biocenoses across a key climatostratigraphic boundary between the Piacenzen and the Gelasian ages. This boundary separates the relatively warm global conditions of the Pliocene from the increasingly cool "ice-age" climates of the Pleistocene. The vegetation during the earliest Pleistocene is closed Larix-Betula-Alnus forest and represents the climatic optimum for MIS 102 and MIS 103, the latter stage spanning the above boundary. This vegetation contrasts to that of the latest Pliocene, when Larix forest-tundra established under conditions that were cooler and drier than during the Early Pleistocene. A steady deterioration of climate following the optimum is indicated by the continued decrease in forest and increase in tundra until $\sim 2560.9 \mathrm{ka}$. At that time, forest communities 
become more widespread, although forest-tundra remained as the regional vegetation. By $\sim 2558.5$, forest again was common in the El'gygytgyn region. However, this forest was dominated by Larix and Betula and contrary to the earlier forested period was associated with wetter landscapes. Even during the coolest conditions, the palynological data from MIS 102 indicate the persistence of forest-tundra. These communities differ significantly from herb-dominated tundra, which characterize glacial stages following the build-up of continental-scale ice sheets in the Northern Hemisphere. As noted by Andreev et al. (2016), the $2.58 \mathrm{Ma}$ boundary separating the Pliocene and Pleistocene does not mark an abrupt climate change from a "warm" to "cold" Arctic. As further remarked by Head and Gibbard (2015), the onset of glacial conditions during the Pleistocene were the result of complex interactions between globalscale forcing mechanisms (e. g., orbital parameters) with feedbacks among the atmosphere, biosphere, and oceans.

This research was funded by the Russian Fund for Basic Research (Research project No. 19-05-00477). Coring operations were supported by the ICDP, the Far East Branch of the Russian Academy of Sciences, the Russian Foundation for Basic Research, the U. S. National Science Foundation, the German Federal Ministry of Education and Research, the Alfred Wegener Institute and Helmholtz Centre Potsdam, and the Austrian Federal Ministry of Science and Research. We thank L. N. Kotova for help in palynological analysis.

\section{REFERENCES}

Anderson, P. M.; Lozhkin, A. V.; Belaya, B. V.; Stetsenko, T. V., 2002a, Modern Spore-Pollen Spectra from the Mountain Regions of the Kolyma and Indigirka Rivers from Lacustrine Sediments, Quaternary Paleogeography of Beringia, Ed. K. V. Simakov, Magadan, NEISRI FEB RAS, 28-39 [In Russian].

Anderson, P. M.; Lozhkin, A. V.; Belaya, B. V.; Stetsenko, T. V., 2002b, Modern Spore-Pollen Spectra of Northern Priokhotye from Lacustrine Sediments, Ibid., 51-61 [In Russian].

Andreev, A. A.; Tarasov, P. E.; Wennrich, V.; Raschke, E.; Herzschuh, U.; Nowaczyk, N. R.; Brigham-Grette, J.; Melles, M., 2014, Late Pliocene and Early Pleistocene Vegetation History of Northeastern Russian Arctic Inferred from the Lake El'gygytgyn Pollen Record, Climate of the Past, 10, 1017-1039.

Andreev, A. A.; Tarasov, P. E.; Wennrich, V.; Melles, M., 2016, Millennial-Scale Vegetation Changes in the North-Eastern Russian Arctic during the Pliocene/ Pleistocene Transition (2.7-2.5 Ma) Inferred from the Pollen Record of Lake El'gygytgyn, Quaternary Science Reviews, 147, 245-256.

Bigelow, N. H.; Brubaker, L. B.; Edwards, M. E.; Harrison, S. P.; Prentice, I. C.; Anderson, P. M.; Andreev, A. A.; Bartlein, P. J.; Christiansen, T. R.; Cramer, W.; Kaplan, J. O.; Lozhkin, A. V.; Matveyeva, N. V.; Murray, D. F.; McGuire, A. D.; Razzhivin, V. Y.; Ritchie, J. C., Smith, B.; Walker, D. A.; Clayden, S. L.; Ebel, T.;
Gajewski, K.; Hahne, J.; Holmqvist, B. H.; Igarashi, Y.; Jordan, J. W.; Kremenetski, K. V.; Melles, M.; Oswald, W. W.; Paus, A.; Pisaric, M. F. J.; Shilova, G. N.; Seigert, C.; Volkova, V. S.; Wolf, V. G., 2003, Climate Change and Arctic Ecosystems: 1. Vegetation Changes North of $55^{\circ} \mathrm{N}$ between the Last Glacial Maximum, Mid-Holocene, and Present, Journal of Geophysical Research, 108 (D19), 1870, Alt11-1 - Alt11-25.

Brigham-Grette, J.; Melles, M.; Minyuk, P.; Andreev, A.; Tarasov, P.; Deconto, R.; Konig, S.; Nowaczyk, N.; Wennrich, V.; Rosen, P.; Haltia, E.; Cook, T.; Gebhardt, C.; Meyer-Jacob, C.; Synder, J.; Herzschuh, U., 2013, Pliocene Warmth, Polar Amplification, and Stepped Pleistocene Cooling Recorded in NE Arctic Russia, Science, 340, 1421-1427.

Gibbard, P. L.; Head, M. J.; Walker, M. J. C. and the Subcommission on Quaternary Stratigraphy, 2010, Formal Ratification of the Quaternary System/Period and the Pleistocene Series/Epoch with a Base at $2.58 \mathrm{Ma}$, Journal of Quaternary Science, 25 (2), 96-102.

Head, M. J.; Gibbard, P. I., 2015, Early-Middle Pleistocene Transitions, Linking Terrestrial and Marine Realms, Quaternary International, 389, 7-46.

Lisiecki, L. E.; Raymo, M. E., 2005, A PliocenePleistocene Stack of 57 Globally Distributed Benthic $\delta{ }^{18} \mathrm{O}$ Records, Paleoceanography, 20, PA10003.

Lourens, L. J., 2008, On the Neogene - Quaternary Debate, Episodes, 31, 239-242.

Lozhkin, A. V.; Anderson, P. M.; Belaya, B. V.; Stetsenko, T. V., 2002, Reflections on Modern Pollen Rain of Chukotka from Bottom Lake Sediments, Ed. K. V. Simakov, Quaternary Paleogeography of Beringia, 40-50, NEISRI FEB RAS, Magadan [In Russian].

Lozhkin, A. V.; Anderson, P. M.; Matrosova, T. V.; Minyuk, P. S., 2007, The Pollen Record from El'gygytgyn Lake: Implications for Vegetation and Climate Histories of Northern Chukotka Since the Late Middle Pleistocene, Journal of Paleolimnology, 37, 135-153.

Matrosova, T. V., 2009, Change of Vegetation and Climate of Northern Chukotka in the Last 350 Thousand Years (from Palynological Data from Lake El'gygytgyn Sediments), Vestnik NESC FEB RAS, 2, 23-30 [In Russian].

Melles, M.; Brigham-Grette, J.; Minyuk, P. S.; Nowaczyk, N.R.; Wennrich, V.; DeConto, R.M.; Anderson, P.M.; Andreev, A. A.; Coletti, A.; Cook, T. L.; Haltia-Hovi, E.; Ukkonen, M.; Lozhkin, A. V.; Rosŭn, P.; Tarasov, P.; Vogel, H.; Wagner, B., 2012, 2.8 Million Years of Arctic Climate Change from Lake El'gygytgyn, NE Russia, Science, 337, 315-320.

Prentice, I. C.; Cramer, W.; Harrison, S. P.; Leemans, R.; Monserund, R. A.; Solomon, A. M., 1992, A Global Biome Model Based on Plant Physiology and Dominance, Soil Pproperties, and Climate, Journal of Biogeography, 19, 117-134.

Rio, D.; Sprovieri, R.; Castradori, D.; Di Stefano, E., 1998, The Gelasian Stage (Upper Pliocene): a New Unit of the Global Chronostratigraphic Scale, Episodes, 21, 82-87.

Tarasov, P. E.; Andreev, A.A.; Anderson, P. M.; Lozhkin, A. V.; Haltia, E.; Nowaczyk, N.R .; Wennrich, V.; BrighamGrette, J.; Melles, M., 2013, The Biome Reconstruction Approach as a Tool for Interpretation of Past Vegetation 
and Climate Changes: Application to Modern and Fossil Pollen Data from Lake El'gygytgyn, Far East Russian Arctic, Climate of the Past Discussion, 9, 3449-3487.

Tarasov, P.E.; Webb III, T.; Andreev, A.A.; Afanas'eva, N. B.; Berezina, N. A.; Bezusko, L. G.; Blyakharchuk, T. A.; Bolikhovskaya, N. S.; Cheddadi, R.; Chernavskaya, M.M.; Chernova, G.M.; Dorofeyuk, N.I.; Dirksen, V. G.; Elina, G. A.; Filimonova, L. V.; Glebov, F. Z.; Guiot, J.; Gunova, V. S.; Harrison, S. P.; Jolly, D.; Khomutova, V. I.; Kvavadze, E. V.; Osipova, I. M.; Panova, N. K.; Prentice, I. C.; Saarse, L.; Sevastyanov, D. V.; Volkova, V. S.; Zernitskaya, V. P., 1998, Present-Day and Mid-Holocene Biomes Rreconstructed from Pollen and Plant Macrofossil Data from the Former Soviet Union and Mongolia, Journal of Biogeography, 25, 10291053.

Received 15.04.2019

Received after revision 22.04.2019
Vas'kovsky, A. P., 1959, Brief Sketch of the Vegetation, Climate, and Chronology of the Quaternary Period in the Upper Reaches of the Kolyma and Indigirka Rivers and on the Northern Coast of the Sea of Okhotsk, Ed. K. K. Markov, Ice Age in the European Part of the USSR and Siberia, Moscow, Lomonosov Moscow State University, 510-545 [In Russian].

Wennrich, V.; Andreev, A.; Tarasov, P.; Fedorov, G.; Zhao, W.; Gerhardt, C.; Meyer-Jacob, C.; Synder, J.; Nowaczyk, N.; Schwamborn, G.; Chaplin, B.; Anderson, P. M.; Lozhkin, A. V.; Minyuk, P. S.; Koeberl, C.; Melles, M., 2016, Impact Processes, Permafrost Dynamics, and Climate and Environmental Variability in the Terrestrial Arctic as Inferred from the Unique 3.6 Myr Record of Lake El'gygytgyn, Far East Russia - a Review, Quaternary Science Reviews, 147, 221-244.

\title{
РАСТИТЕЛЬНОСТЬ ВОСТОЧНОЙ АРКТИКИ 2.595-2.554 млН лет назад (данные по оз. Эльгыгытгын, Северо-Восток России)
}

\author{
А. В. Ложкин ${ }^{1}$ А. А. Андреев ${ }^{2,4}$, П. М. Андерсон ${ }^{3}$ Ю. А. Корзун ${ }^{1}$, Е. Ю. Недорубова ${ }^{I}$ \\ ${ }^{I}$ ФГБУН Северо-Восточный комплексный научно-исследовательский институт \\ им. Н. А. Шило ДВО РАН, г. Магадан \\ ${ }^{2}$ Институт Альфреда Вегенера Гельмгольиа Центр полярных и морских исследований, \\ 2. Потсдам, Германия \\ ${ }^{3}$ Вашингтонский университет, факультет наук о Земле и Космосе, \\ Центр четвертичных исследований, г. Сиэтл, США \\ ${ }^{4}$ Институт геологии и нефтегазовых технологий, Казанский федеральный университет, \\ 2. Казань, Россия
}

Граница плиоцена и плейстоцена, установленная на уровне 2.588 млн л. н. (основание гелазия), характеризует изменение глобального климата от климата сравнительно теплого в плиоцене к более холодным условиям плейстоцена. Одну из немногих непрерывных наземных записей изменений климата дают осадки оз. Эльгыгытгын (северная Чукотка). Эта запись позволяет изучить важный переход в климатической истории Земли. Палинологические данные изотопных стадий MIS 102 и MIS 103 в летописи оз. Эльгыгытгын указывают на то, что в самом раннем плейстоцене в этой области Арктики господствовали леса, образованные лиственницей, березой, ольхой. Такая растительность раннего плейстоцена резко отличается от растительности конца плиоцена, когда доминировали лиственничная лесотундра и травянисто-кустарниковая тундра, встречающаяся сегодня на севере Чукотки. Самый ранний период гелазия является климатическим оптимумом для MIS 103. Даже в суровых условиях во время MIS 102 сохранилась лиственничная лесотундра, резко отличающаяся от травянистой тундры, характеризовавшей многие ледниковые интервалы в Арктике во время среднего и позднего плейстоцена.

Ключевые слова: гелазий, плейстоцен, плиоцен, спорово-пыльцевой анализ, палеорастительность.

\section{ЛИТЕРАТУРА}

Андерсон П. М., Ложкин А. В., Белая Б. В., Стеизенко T. В. Современные спорово-пыльцевые спектры горных районов рек Колыма и Индигирка по данным озерных осадков // Четвертичная палеогеография Берингии / под ред. К. В. Симакова. Магадан : СВКНИИ ДВО РАН, 2002а. С. 28-39.

Андерсон П. М., Ложкин А. В., Белая Б. В., Стеценко T. В. Современные спорово-пыльцевые спек- тры Северного Приохотья по данным озерных осадков // Там же. Магадан : СВКНИИ ДВО РАН, 2002б. C. $51-61$.

Васьковский А. П. Краткий очерк растительности, климата и хронологии четвертичного периода в верховьях рек Колымы, Индигирки и на северном побережье Охотского моря // Ледниковый период на территории европейской части СССР и Сибири / под 
ред. К. К. Маркова. М. : Изд-во МГУ, 1959. С. 510545.

Ложкин А. В., Андерсон П. М., Белая Б. В., Стеиенко T. $B$. Отражение современного пыльцевого дождя Чукотки в донных осадках озер // Четвертичная палеогеография Берингии / под ред. К. В. Симакова. Магадан : СВКНИИ ДВО РАН, 2002. С. 40-50.

Матросова Т. В. Изменение растительности и климата северной Чукотки за последние 350 тыс. лет (по палинологическим данным осадков оз. Эльгыгытгын) // Вестник СВНЦ ДВО РАН. 2009. № 2. C. 23-30.

Andreev A. A., Tarasov P. E., Wennrich V., et al. Late Pliocene and early Pleistocene vegetation history of northeastern Russian Arctic inferred from the Lake El'gygytgyn pollen record // Climate of the Past. 2014. Vol. 10. P. 1017-1039.

Andreev A. A., Tarasov P. E., Wennrich V., Melles M. Millennial-scale vegetation changes in the north-eastern Russian Arctic during the Pliocene/Pleistocene transition (2.7-2.5 Ma) inferred from the pollen record of Lake El'gygytgyn // Quaternary Science Reviews. 2016. Vol. 147. P. 245-256.

Bigelow N. H., Brubaker L. B., Edwards M. E., et al. Climate change and Arctic ecosystems: 1. Vegetation changes north of $55^{\circ} \mathrm{N}$ between the last glacial maximum, mid-Holocene, and present // Journal of Geophysical Research, 108 (D19), 1870, Alt11-1 Alt11-25. 2003.

Brigham-Grette J., Melles M., Minyuk P., et al. Pliocene warmth, polar amplification and stepped Pleistocene cooling recorded in NE Arctic Russia // Science. 2013. Vol. 340. P. 1421-1427.

Gibbard P. L., Head M. J., Walker M. J. C. And the Subcommission on Quaternary Stratigraphy. Formal ratification of the Quaternary system/period and the Pleistocene series/epoch with a base at 2.58 Ma // Journal of Quaternary Science. 2010. Vol. 25 (2). P. 96-102.

Head M. J., Gibbard P. I. Early-Middle Pleistocene Transitions: Linking Terrestrial and Marine
Realms / Quaternary International. 2015. Vol. 389. P. 7-46.

Lisiecki L. E., Raymo M. E. A Pliocene-Pleistocene stack of 57 globally distributed benthic $\delta{ }^{18} \mathrm{O}$ records // $\mathrm{Pa}$ leoceanography. 2005. Vol. 20, PA10003.

Lourens L. J. On the Neogene - Quaternary debate // Episodes. 2008. Vol. 31. P. 239-242.

Lozhkin A. V., Anderson P. M., Matrosova T. V., Minyuk P. S. The pollen record from El'gygytgyn Lake: implications for vegetation and climate histories of northern Chukotka since the late middle Pleistocene // Journal of Paleolimnology. 2007. Vol. 37. P. 135-153.

Melles M., Brigham-Grette J., Minyuk P. S., et al. 2.8 Million Years of Arctic Climate Change from Lake El'gygytgyn, NE Russia // Science. 2012. Vol. 337. P. 315-320.

Prentice I. C., Cramer W., Harrison S. P., et al. A global biome model based on plant physiology and dominance, soil properties and climate // Journal of Biogeography. 1992. Vol. 19. 117-134.

Rio D., Sprovieri R., Castradori D., Di Stefano E. The Gelasian Stage (Upper Pliocene): a new unit of the global chronostratigraphic scale // Episodes. 1998. Vol. 21. P. 82-87.

Tarasov P. E., Webb III, T., Andreev A. A., et al. Present-day and mid-Holocene biomes reconstructed from pollen and plant macrofossil data from the former Soviet Union and Mongolia // Journal of Biogeography. 1998. Vol. 25. P. 1029-1053.

Tarasov P. E., Andreev A. A., Anderson P. M., et al. The biome reconstruction approach as a tool for interpretation of past vegetation and climate changes: Application to modern and fossil pollen data from Lake El'gygytgyn, Far East Russian Arctic // Climate of the Past Discussion. 2013. Vol. 9. P. 3449-3487.

Wennrich V., Andreev A., Tarasov P., et al. Impact processes, permafrost dynamics, and climate and environmental variability in the terrestrial Arctic as inferred from the unique 3.6 myr record of Lake El'gygytgyn, Far East Russia - a review // Quaternary Science Reviews. 2016. Vol. 147. P. 221-244. 